Article

\title{
Improving Electrochromic Cycle Life of Prussian Blue by Acid Addition to the Electrolyte
}

\author{
ZiTong Li, YunHui Tang *, KaiLing Zhou, Hao Wang * and Hui Yan \\ The College of Materials Science and Engineering, Beijing University of Technology, Beijing 100124, China; \\ xukun188@emails.bjut.edu.cn (Z.L.); zkling@emails.bjut.edu.cn (K.Z.); hyan@bjut.edu.cn (H.Y.) \\ * Correspondence: tangyh@bjut.edu.cn (Y.T.); haowang@bjut.edu.cn (H.W.)
}

Received: 8 November 2018; Accepted: 13 December 2018; Published: 21 December 2018

check for updates

\begin{abstract}
In this study, we examined the cyclic stability of Prussian blue (PB) films in electrolytes with acid. The cyclic stabilities of the PB films were investigated in $\mathrm{K}^{+}$based electrolytes with different values of solution $\mathrm{pH}$. The acidified $\mathrm{KCl}$ solution can significantly improve the durability of the film. Among the three $\mathrm{pH}$ values tested, the $\mathrm{KCl}$ solutions $(\mathrm{pH}=2.15$ and $\mathrm{pH}=3.03)$ showed better performance. Furthermore, we investigated the cyclic stabilities of the PB films in $\mathrm{LiClO}_{4} / \mathrm{PC}$ electrolyte containing different acids. We found that the cyclic stability of PB film was significantly improved when a small amount of acetic acid was dissolved in $\mathrm{LiClO}_{4} / \mathrm{PC}$ electrolyte. The PB film exhibited stable optical modulation after up to 20,000 cycles in $\mathrm{LiClO}_{4} / \mathrm{PC}$ electrolyte containing acetic acid - a much higher result than those of some literatures. This suggests that the addition of acetic acid to $\mathrm{LiClO}_{4} / \mathrm{PC}$ electrolyte can promote the development of PB-based devices with improved stability.
\end{abstract}

Keywords: electrochromism; Prussian blue; cycle life

\section{Introduction}

Electrochromism refers to the phenomenon that materials can switch their optical properties reversibly by applying an external potential or current [1]. Recently, numerous electrochromic materials have been investigated for their high optical modulation, great stability, and simple preparation, such as $\mathrm{WO}_{3}, \mathrm{NiO}$, and polyaniline [2-7]. These materials have been widely applied for various applications such as switchable windows [8], electrochromic displays [9], rechargeable batteries [10], and optical attenuators [11].

Fe complexes [12-15] also exhibit potential applications in the field of electrochromism. Among these Fe complexes, Prussian blue (PB, an iron (II,III) hexacyanoferrate (II,III)) gains much attention for its high redox reversibility and low threshold potential [16]. Prussian blue is a coordination compound, which can change optical properties by intercalating or de-intercalating ions. Many electrochromic devices (ECD) employ PB as the complementary electrochromic material. Examples include $\mathrm{PB} /$ tungsten oxide [17,18], $\mathrm{PB} /$ poly (butyl viologen) [19], and $\mathrm{PB} /$ poly (3,4-ethylenedioxythiophene) (PEDOT) [20]. However, the cycle life of the PB film is generally only about 100 cycles. The poor durability of Prussian blue films restricts its applications in an electrochromic field. Some researchers tried to solve this problem by improving the preparation method. Qian et al. [21] reported that nanostructured PB films could be grown using a template-free hydrothermal technique. The film possessed cycling stability after 150 cycles. Wang et al. [22] synthesized PB film via an electrochemical post-treatment procedure. The resulting PB film exhibited improved stability in neutral and alkaline solutions after 500 cycles. Meanwhile, some researchers tried to synthesize a PB hybrid film. Cheng et al. [23] fabricated a nanocomposite Prussian blue (NPB) film composed of the random packing of ITO nanoparticles. The NPB film exhibited a high optical 
modulation and slight charge density decay after 2000 cycles. Seelandt et al. [24] used a $\mathrm{TiO}_{2}$ thin film possessing an ordered array of mesopores to support $\mathrm{PB}$. The $\mathrm{PB} / \mathrm{TiO}_{2}$ hybrid film had high optical modulation $(\Delta \mathrm{T}=65 \%)$ and fast switching speed $\left(\mathrm{T}_{\mathrm{c}}=3 \mathrm{~s}, \mathrm{~T}_{\mathrm{b}}=2 \mathrm{~s}\right)$ after 400 cycles. In addition, some researchers tried to improve the electrolyte performance. Wang et al. [18] reported the synthesis of a poly (methyl methacrylate)-succinonitrile composite polymer electrolyte which was then applied to $\mathrm{WO}_{3} / \mathrm{PB}$ complementary electrochromic devices. The $\Delta \mathrm{T}$ of this device lost $15 \%$ of its original value after 2250 cycles. Nonetheless, the methods mentioned above do not significantly improve the cycle life of the PB film, and the film generally exhibits obvious optical modulation decay after 2500 cycles.

In this work, the cyclic stabilities of PB films were investigated in $\mathrm{K}^{+}$-based electrolytes with different values of solution $\mathrm{pH}$. Meanwhile, we investigated the influence of adding different acids (hydrochloric acid and acetic acid) to $\mathrm{LiClO}_{4} / \mathrm{PC}$ electrolyte on the cycle life of the PB films. The cyclic stability of the PB films exhibited significant improvement when acetic acid was dissolved in $\mathrm{LiClO}_{4} / \mathrm{PC}$ electrolyte.

\section{Experimental}

\subsection{Materials}

All the chemicals were used without further purification. Potassium ferricyanide, acetone, ethanol, hydrochloric acid, acetic acid, iron (III) chloride, and potassium chloride were all obtained from Beijing Chemical Works. Lithium perchlorate and propylene carbonate were purchased from Damao Chemical Reagent Factory. Indium tin oxide (ITO) glasses $\left(3 \times 4 \mathrm{~cm}^{2}\right.$ in size and sheet resistant Rs $\left.\approx 20 \Omega\right)$ were used as the substrates. All experiments were performed at room temperature in air.

\subsection{Sample Preparation}

PB films were deposited on the ITO substrates that were cleaned in acetone, ethanol, and deionized water successively using ultrasound. In a typical route, a plating solution of PB film was prepared, consisting of $10 \mathrm{mM} \mathrm{K}_{3}\left[\mathrm{Fe}(\mathrm{CN})_{6}\right], 10 \mathrm{mM} \mathrm{FeCl}_{3}$, and $0.1 \mathrm{M} \mathrm{KCl}$ with dilute $\mathrm{HCl}$ to adjust to the $\mathrm{pH}$ to 2 . ITO substrates, a Pt plate, and an $\mathrm{Ag} / \mathrm{AgCl}$ electrode were used as the working electrode, the counter electrode, and the reference electrode, respectively. The electroplating was carried out galvanostatically for $15 \mathrm{~min}$ by applying cathodic current densities of $10 \mu \mathrm{A} / \mathrm{cm}^{2}$ at room temperature. After the deposition, the samples were washed by distilled water and then dried in air before proceeding with future experiments.

\subsection{Characterization and Electrochemical Measurements}

The morphologies of the films were measured by scanning electron microscope (SEM, FEI Quanta 650). The cyclic voltammetry (CV) and chronoamperometry measurements were carried out using a Princeton VersaSTAT 4 electrochemical workstation in a three-electrode electrochemical cell with $\mathrm{Ag} / \mathrm{AgCl}$ as the reference electrode, $\mathrm{PB}$ as the work electrode, Pt plate as the counter electrode, and $1 \mathrm{M}$ $\mathrm{KCl}$ solution or $1 \mathrm{M} \mathrm{LiClO}_{4}$ / propylene carbonate (PC) as the electrolyte. The in situ observation of the optical transmittance of the PB films at $690 \mathrm{~nm}$ was measured using an ultraviolet-visible-near-infrared spectrophotometer (Shimadzu UV-3101PC) combined with a square quartz groove $\left(5.5 \times 5.5 \times 5 \mathrm{~cm}^{3}\right)$ during all electrochemical cycling.

\section{Results and Discussion}

Figure 1a-d show the $\mathrm{CV}$ curves of the PB film in neutral and acidified $\mathrm{KCl}$ solution. The applied potential is set between -0.2 and $0.8 \mathrm{~V}$ relative to the $\mathrm{Ag} / \mathrm{AgCl}$ reference electrode with the potential sweep rate of $50 \mathrm{mV} / \mathrm{s}$. As shown in Figure 1a, there are two redox peaks: one at $0.14 \mathrm{~V}$ (PB/Prussian 
white (PW)) and another at $0.8 \mathrm{~V}(\mathrm{~PB} /$ Prussian yellow (PY)). The two redox peaks are identified as PB reducing to $\mathrm{PW}$ and as $\mathrm{PB}$ oxidizing to $\mathrm{PY}$, as in the following reactions [25]:

$$
\mathrm{KFe}\left[\mathrm{Fe}(\mathrm{CN})_{6}\right]+\mathrm{K}^{+}+e^{-} \leftrightarrow \mathrm{K}_{2} \mathrm{Fe}\left[\mathrm{Fe}(\mathrm{CN})_{6}\right]
$$

PB PW

$$
\mathrm{KFe}\left[\mathrm{Fe}(\mathrm{CN})_{6}\right] \leftrightarrow \mathrm{Fe}\left[\mathrm{Fe}(\mathrm{CN})_{6}\right]+\mathrm{K}^{+}+e^{-}
$$

PB PY

The PB film shows definite separations of voltammetric peaks for the reduction and oxidation, which can be attributed to the resistivity of the ITO substrate layer [26]. In addition, the peak current density of $\mathrm{PB} / \mathrm{PW}$ is higher than that of $\mathrm{PY} / \mathrm{PB}$ in the testing. On the one hand, the $\mathrm{PB}$ structure only contains $3 \mathrm{Fe}^{2+}$ sites (involved in $\mathrm{PB} / \mathrm{PY}$ ) by each $4 \mathrm{Fe}^{3+}$ (involved in $\mathrm{PB} / \mathrm{PW}$ ), so not all oxidized $\mathrm{Fe}^{2+}$ may be balanced by cations [27]. On the other hand, the CV curves were measured in the potential cycled from -0.2 to $0.8 \mathrm{~V}$. The redox reaction of $\mathrm{PB} / \mathrm{PY}$ is not sufficient in this range.
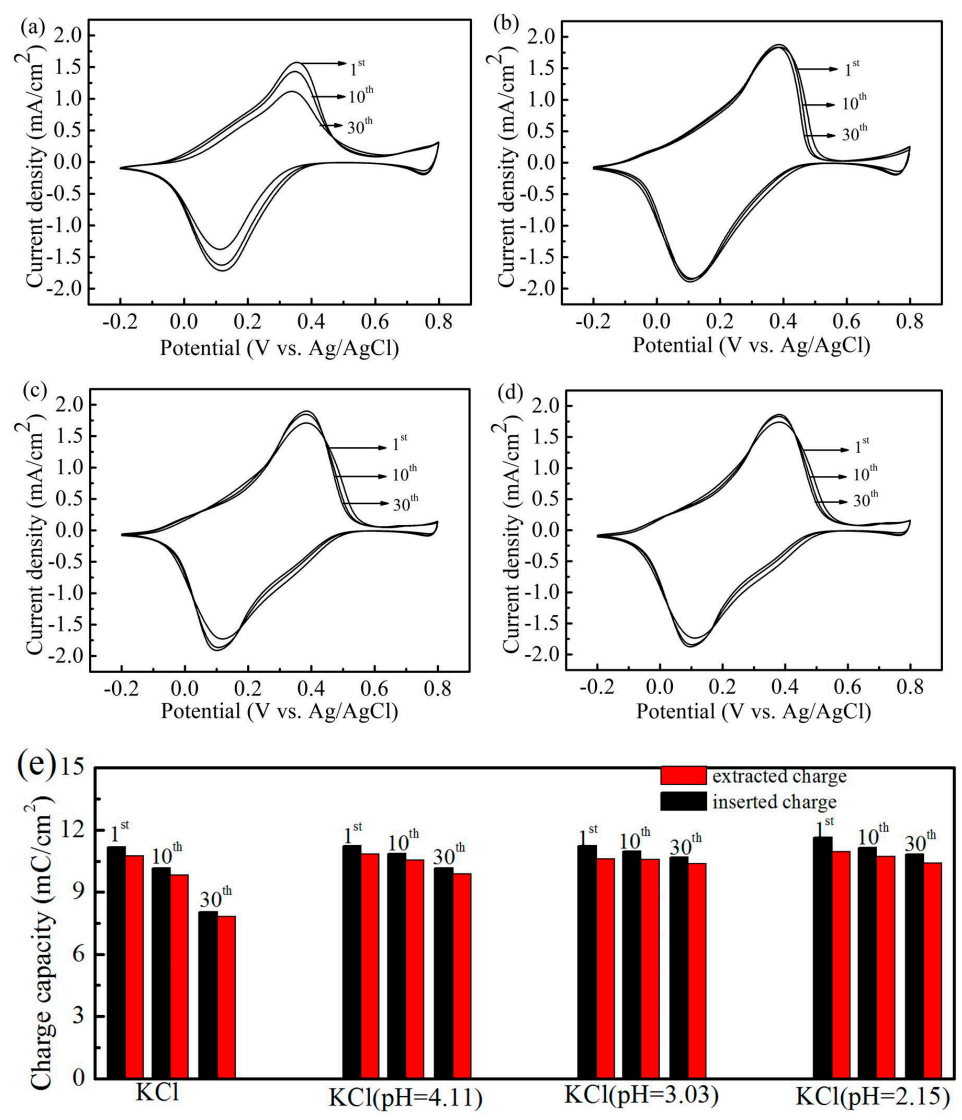

Figure 1. Cyclic voltammograms of Prussian blue (PB) film in (a) neutral $1 \mathrm{M} \mathrm{KCl}$ solution, and $\mathrm{KCl}$ aqueous solution with different values of solution $\mathrm{pH}$ : (b) 4.11, (c) 3.03, and (d) 2.15. (e) Inserted and extracted charge densities versus cycle number derived from the cyclic voltammetry $(\mathrm{CV})$ data.

As shown in Figure 1a, we failed to establish any long cycling stability of the PB film in neutral $\mathrm{KC} 1$ solutions due to the strong interaction between ferric ions and hydroxide ions. However, the remarkable durability of the film was observed in acidified $\mathrm{KCl}$ solutions, and these results are consistent with those reported in some research works [28]. Figure $1 \mathrm{~b}-\mathrm{d}$ show the CV curves of the $\mathrm{PB}$ films in acidified $\mathrm{KCl}$ solution with hydrochloric acid; the values of the solution $\mathrm{pH}$ are $4.11,3.03$, and 2.15, respectively. The PB films retained their CV shape without significant decay in 30 cycles compared to Figure 1a,e, which show the charge capacity, calculated by integrating the 
insertion/extraction parts of CV data, during 30 cycles. Our results show a slight difference between inserted and extracted charges in the one cycle. This indicates that the partially inserted ions cannot completely be extracted in one cycle. We attribute this phenomenon to the insufficiency of the PB/PY reaction. The charge capacity of the 30 th cycle was $72 \%$ of the initial value in neutral $\mathrm{KCl}$ solution. The values tested in acidified $\mathrm{KCl}$ solution exceeded $90 \%$ and were clearly higher than those of the neutral $\mathrm{KCl}$ solution. The results imply that the acidified $\mathrm{KCl}$ solution can significantly improve the durability of the film, and the $\mathrm{KCl}$ solutions $(\mathrm{pH}=2.15$ and $\mathrm{pH}=3.03)$ show better performance.

The potential steps of -0.05 and $0.5 \mathrm{~V}$ were applied for $10 \mathrm{~s}$ to investigate the cyclic stability of the PB film in $\mathrm{KCl}(\mathrm{pH}=3.03)$. The corresponding in situ transmittance responses at $690 \mathrm{~nm}$ are shown in Figure 2. There was no significant degradation of the PB film after 3000 cycles.

When the acidified $\mathrm{KCl}$ solution was employed as an electrolyte for the PB-based ECD, it was difficult to seal the ECD completely to prevent solution leakage. Furthermore, we cannot neglect the security issue of this $\mathrm{ECD}$ because the value of the $\mathrm{KCl}$ solution $\mathrm{pH}$ is 3. So, replacing the acidified $\mathrm{KCl}$ solution with $\mathrm{LiClO}_{4} / \mathrm{PC}$ electrolyte is a promising option. In the following part, the cyclic stability of the PB film in $\mathrm{LiClO}_{4} / \mathrm{PC}$ electrolyte is investigated. Meanwhile, we discuss the influence of adding strong acid and weak acid to $\mathrm{LiClO}_{4} / \mathrm{PC}$ electrolyte on the cyclic stability of the PB film. The volume ratio of $\mathrm{LiClO}_{4} / \mathrm{PC}$ to acetic acid was 200:1; the volume ratio of $\mathrm{LiClO}_{4} / \mathrm{PC}$ to hydrochloric acid was the same as above.

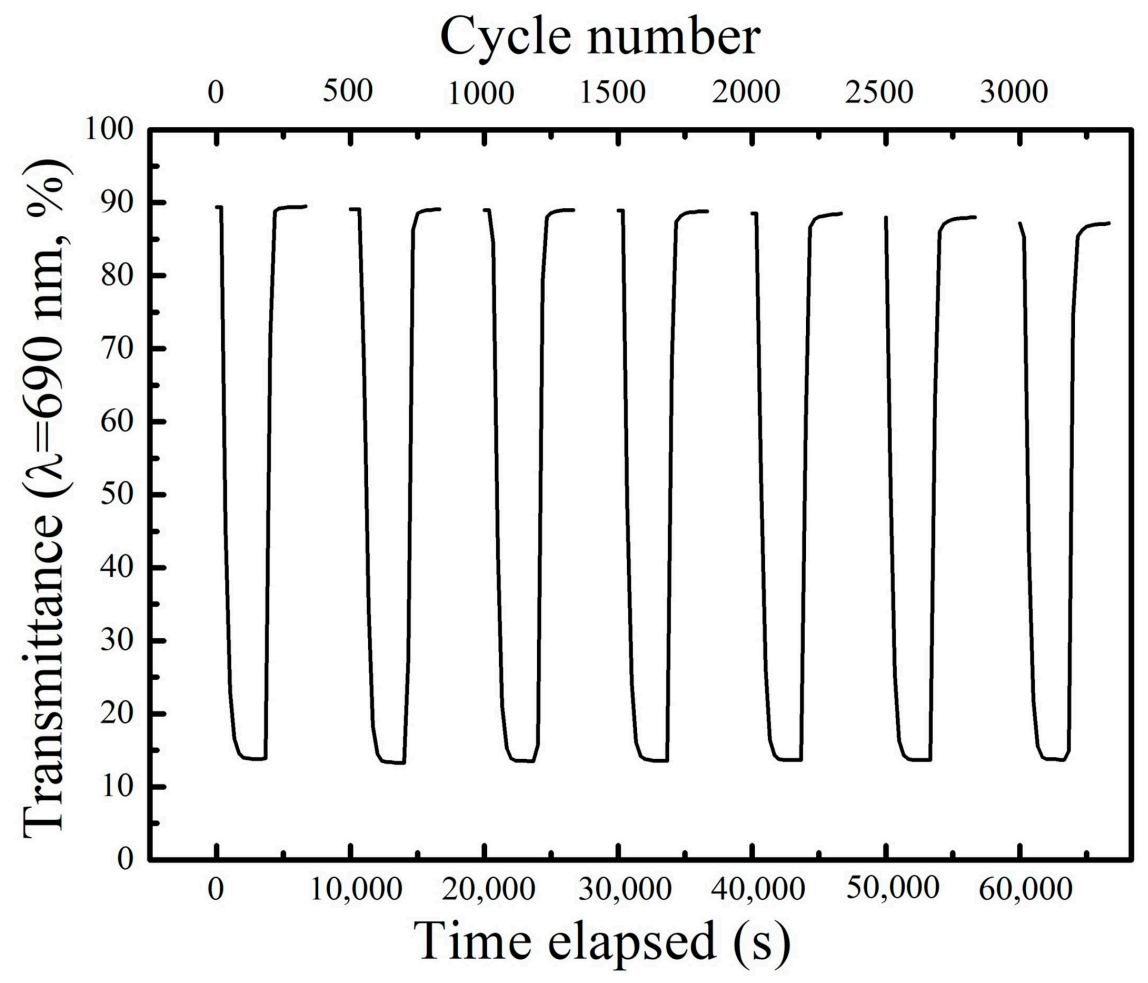

Figure 2. Evolution of optical transmittance spectra at $690 \mathrm{~nm}$ for Prussian blue (PB) film under a step potential varied from $-0.05 \mathrm{~V}$ to $0.5 \mathrm{~V}$ for $10 \mathrm{~s}$ in $\mathrm{KCl}(\mathrm{pH}=3.03)$ solution.

Figure 3 shows the $\mathrm{CV}$ curves of the $\mathrm{PB}$ film in $\mathrm{LiClO}_{4} / \mathrm{PC}$ electrolytes with different levels of acid. Compared with Figure 1, the shift of anodic peaks and cathodic peaks shown in Figure 3 indicates that the redox reaction of the film is diffusion-limited [29]. The interfacial reaction kinetics and transport rate all influence the cycle life of the film. The resistivity of $\mathrm{Li}^{+}$transfer through the interface between the solid electrode and the polymer electrolyte is different from the resistivity of $\mathrm{K}^{+}$transfer through solid/liquid interfaces [30]. The ionic radius of $\mathrm{K}^{+}$and $\mathrm{Li}^{+}$is different, so the rate of ion insertion/extraction is different. Figure 3a shows the $\mathrm{CV}$ results of the PB film tested in pure $\mathrm{LiClO}_{4} / \mathrm{PC}$ electrolyte. The peak current density of PB/PW becomes lower while the peak 
current density of PB/PY becomes higher in the cycling. In addition, the area of CV curves decreases as the number of cycles increases. The results reveal that the redox reaction of PB/PW gradually weakens after the 30 th cycle. Figure $3 \mathrm{~b}$ shows the $\mathrm{CV}$ curves of the film tested in $\mathrm{LiClO}_{4} / \mathrm{PC}$ electrolyte containing hydrochloric acid $\left(\mathrm{LiClO}_{4} / \mathrm{PC} / \mathrm{HCl}\right)$. The results are similar to the former and indicate that the addition of hydrochloric acid has no significant effect on the stability of the PB film. Figure $3 \mathrm{c}$ shows the results of the PB film tested in $\mathrm{LiClO}_{4} / \mathrm{PC}$ electrolyte containing acetic acid $\left(\mathrm{LiClO}_{4} / \mathrm{PC} / \mathrm{HAc}\right)$. The areas of $\mathrm{CV}$ curves and redox peaks of $\mathrm{PB}$ film exhibit no obvious difference between the first and the 30th cycle. The evolution of the charge density of the films is shown in Figure $3 \mathrm{~d}$; it can be clearly seen that the charge density of the film cycling in $\mathrm{LiClO}_{4} / \mathrm{PC} / \mathrm{HAc}$ remains at $94.2 \%$ of the original value, which is much higher than the two other experimental results. The results imply that the addition of acetic acid can improve the durability of the PB film in $\mathrm{LiClO}_{4} / \mathrm{PC}$ electrolyte.
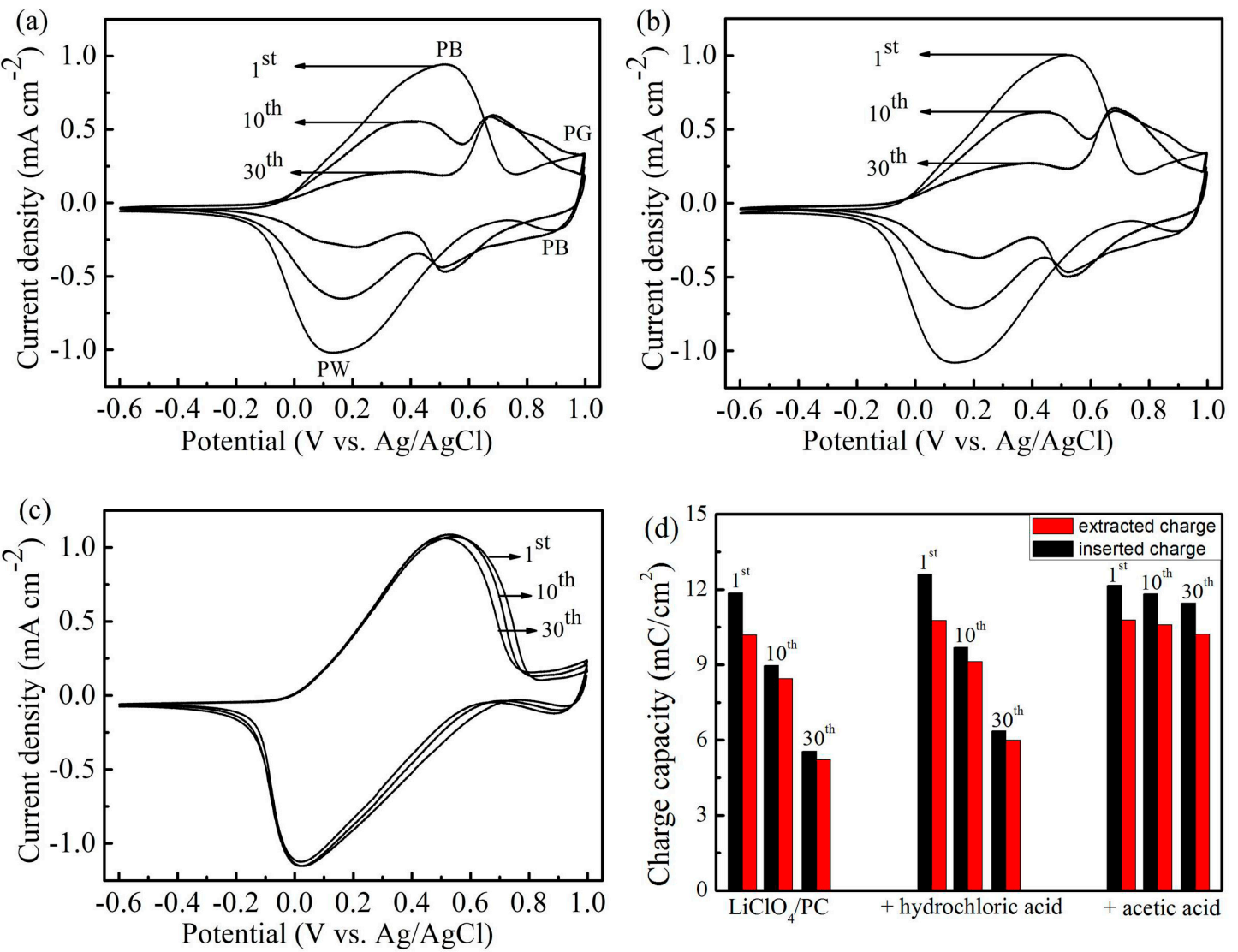

Figure 3. The cyclic voltammetry (CV) evolutions of the Prussian blue (PB) film in $\mathrm{LiClO}_{4} / \mathrm{PC}$ electrolytes with different acid: (a) $\mathrm{LiClO}_{4} / \mathrm{PC}$, (b) $\mathrm{LiClO}_{4} / \mathrm{PC} / \mathrm{HCl}$, and (c) $\mathrm{LiClO}_{4} / \mathrm{PC} / \mathrm{HAc}$. (d) Inserted and extracted charge densities versus cycle number derived from $\mathrm{CV}$ data.

Large optical modulation and long-term durability are the key prerequisites for the practical implementation of electrochromic devices [31]. Here, we employed chronoamperometry and in situ optical transmittance measurements to estimate the influence of different acids (hydrochloric acid and acetic acid) on the cycle life of the PB film in $\mathrm{LiClO}_{4} / \mathrm{PC}$ electrolyte.

As shown in Figure 4a, the in situ optical transmittance at $690 \mathrm{~nm}$ and chronoamperometric responses of the PB films on cycling were synchronously recorded. An upward transmittance curve and negative current responses were recorded when the negative potential was applied; the reduction of $\mathrm{Fe}^{\mathrm{III}}$ to $\mathrm{Fe}^{\mathrm{II}}$ led to the bleaching of the PB film. A downward transmittance curve and positive current responses were recorded when the positive potential was applied; the oxidation of $\mathrm{Fe}^{\mathrm{II}}$ to $\mathrm{Fe}^{\mathrm{III}}$ led to the coloration of the film. Figure $4 \mathrm{~b}$ shows the chronoamperometric curves of the PB 
film in $\mathrm{LiClO}_{4} / \mathrm{PC}$. The peak current densities of the oxidation and reduction reaction reached a maximum at the first cycle and then decreased gradually upon cycling. This indicates that the PB film gradually loses its electrochromic activity in the cycling. Figure 4c shows the curves of the $\mathrm{PB}$ film tested in $\mathrm{LiClO}_{4} / \mathrm{PC} / \mathrm{HCl}$. The results of the chronoamperometric evolution are similar to Figure $4 \mathrm{~b}$, which illustrates that hydrochloric acid cannot improve the durability of $\mathrm{PB}$ film in $\mathrm{LiClO}_{4} / \mathrm{PC}$ electrolyte. Figure $4 \mathrm{~d}$ shows the results of the PB film tested in $\mathrm{LiClO}_{4} / \mathrm{PC} / \mathrm{HAc}$. The peak current densities exhibited no obvious changes upon switching. The cycle life of the PB film tested in $\mathrm{Li}^{+}$-based electrolyte exceed 20,000 cycles, which is much higher than the results reported in some research works. The results indicate that the $\mathrm{PB}$ film tested in $\mathrm{LiClO}_{4} / \mathrm{PC} / \mathrm{HAc}$ possesses stable electrochromic activity. Figure $4 \mathrm{e}-\mathrm{h}$ show the photographs of the as-electrodeposited PB film and the film after testing in $\mathrm{LiClO}_{4} / \mathrm{PC}$ electrolyte containing different acids. Distinct color fading of the film was observed after 100 cycles in $\mathrm{LiClO}_{4} / \mathrm{PC}$ electrolyte and $\mathrm{LiClO}_{4} / \mathrm{PC} / \mathrm{HCl}$. However, the PB film after 20,000 cycles in $\mathrm{LiClO}_{4} / \mathrm{PC} / \mathrm{HAc}$ showed no obvious color change compared to the as-deposited PB film. These results imply that suitable acidic environments can inhibit the decomposition of PB film in $\mathrm{LiClO}_{4} / \mathrm{PC}$ electrolyte and are consistent with the data from the chronoamperometric tests.
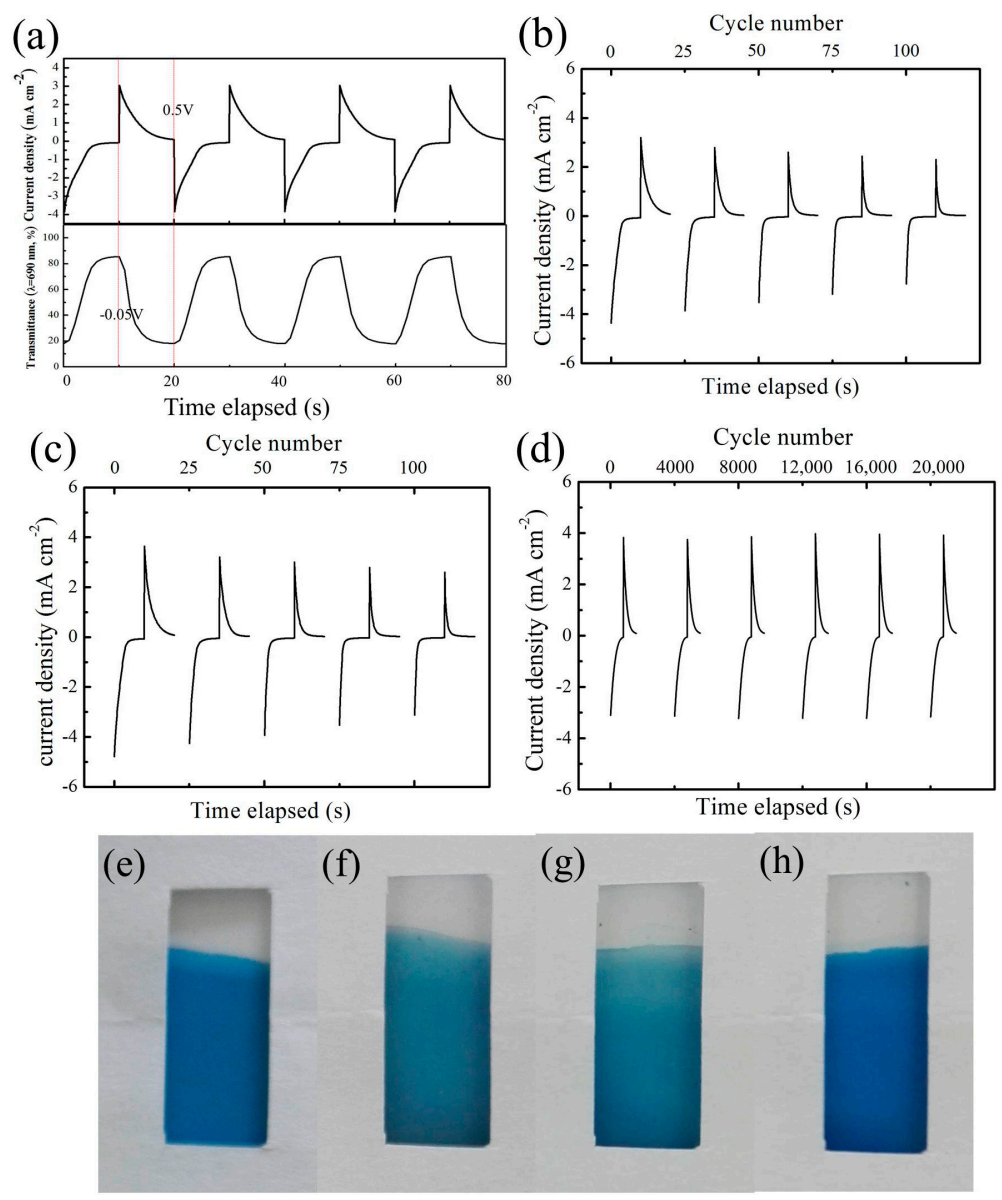

Figure 4. (a) In situ observation of the transmittance at $\lambda=690 \mathrm{~nm}$ at the potential steps of -0.05 $\mathrm{V}$ and $0.5 \mathrm{~V}$. Chronoamperometric curve evolution of the Prussian blue (PB) film in (b) $\mathrm{LiClO}_{4} / \mathrm{PC}$, (c) $\mathrm{LiClO}_{4} / \mathrm{PC} / \mathrm{HCl}$, and (d) $\mathrm{LiClO}_{4} / \mathrm{PC} / \mathrm{HAc}$. (e) The photograph of the as-electrodeposited PB film. The photographs of the PB film after (f) 100 cycles in $\mathrm{LiClO}_{4} / \mathrm{PC}$, (g) 100 cycles in $\mathrm{LiClO}_{4} / \mathrm{PC} / \mathrm{HCl}$, and (h) 20,000 cycles in $\mathrm{LiClO}_{4} / \mathrm{PC} / \mathrm{HAc}$.

Figure 5a shows the evolution of optical transmittance spectra at $\lambda=690 \mathrm{~nm}$ of the PB film cycling in $\mathrm{LiClO}_{4} / \mathrm{PC}$ electrolyte. The initial optical transmittance of the PB film in the bleaching and coloration states was $83.2 \%$ and $22.3 \%$, respectively; hence, the optical modulation was $60.9 \%$. 
However, both the bleaching and coloration curves decayed rapidly with the cycling. The optical modulation was only $20.0 \%$ at the 100 th cycle, which is $32.8 \%$ of the initial cycle. Figure $5 \mathrm{~b}$ shows the results of the $\mathrm{PB}$ film tested in $\mathrm{LiClO}_{4} / \mathrm{PC} / \mathrm{HCl}$. The decay tendency of the optical modulation is similar to that in Figure 5a. In detail, the decreased speed of coloration state is slightly lower in the first 25 cycles than that in Figure $5 \mathrm{a}$. Figure $5 \mathrm{c}$ shows the evolution of optical transmittance spectra of the PB film cycling in $\mathrm{LiClO}_{4} / \mathrm{PC} / \mathrm{HAc}$. There was no obvious degradation of the electrochromic properties after 20,000 cycles. The optical modulation of the PB film at the 20,000th cycle was $60.8 \%$, which is slightly higher than the $57.5 \%$ of the first cycle.
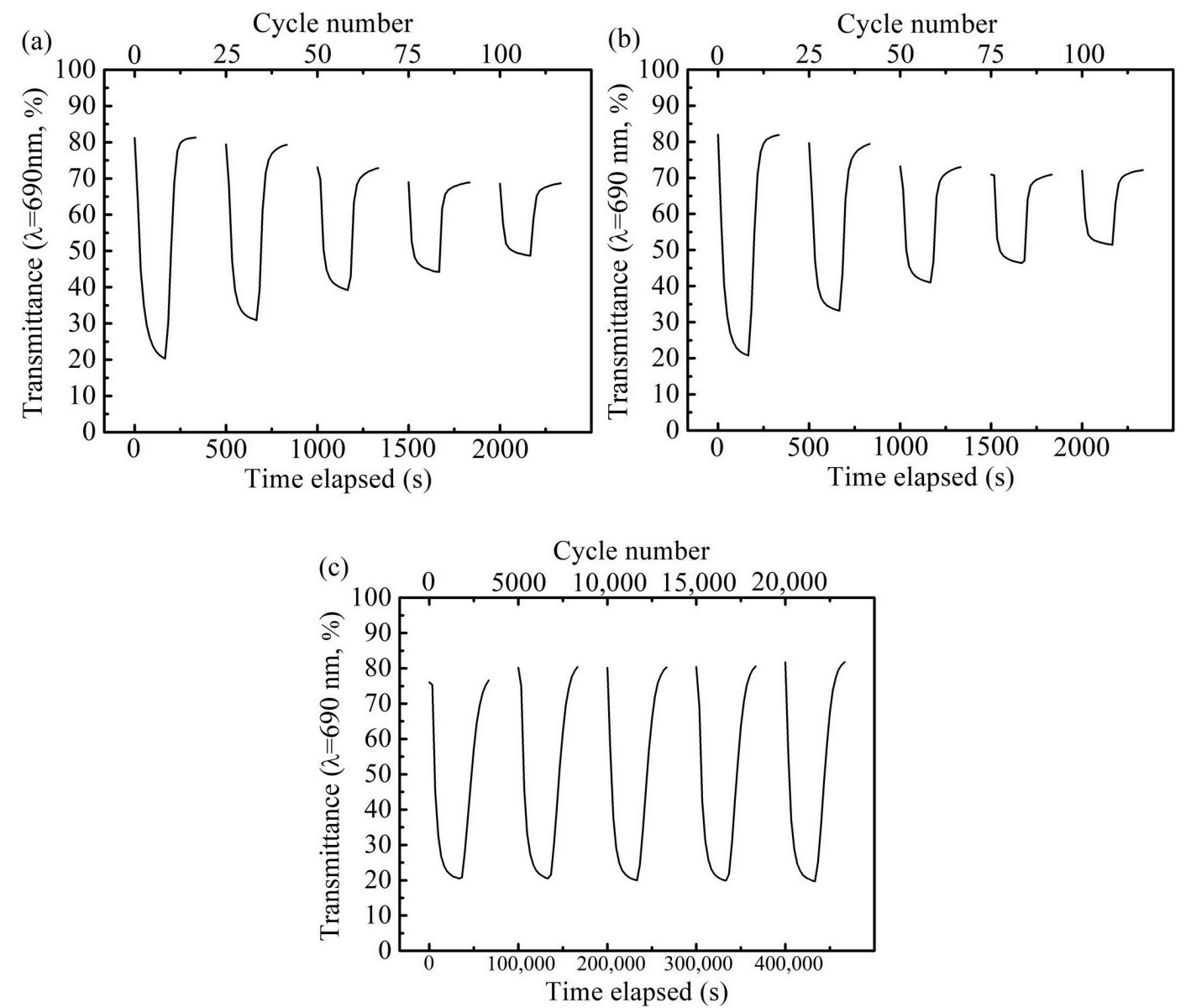

Figure 5. Evolution of the optical transmittance spectra at $690 \mathrm{~nm}$ for the Prussian blue (PB) film in (a) $\mathrm{LiClO}_{4} / \mathrm{PC}$, (b) $\mathrm{LiClO}_{4} / \mathrm{PC} / \mathrm{HCl}$, and (c) $\mathrm{LiClO}_{4} / \mathrm{PC} / \mathrm{HAc}$.

The switching speed at $690 \mathrm{~nm}$ measured from the time dependence of transmittance responses is shown in Figure 6. The switching speed time is defined as the $90 \%$ interval between the bleaching state and coloration state. The coloration time of the film in the three electrolytes is almost the same (3.5 s), while the bleaching time in $\mathrm{LiClO}_{4} / \mathrm{PC} / \mathrm{HAc}$ is $7.1 \mathrm{~s}$, which is obviously larger than the $4 \mathrm{~s}$ of the other two cases. These results indicate that the addition of acetic acid can greatly improve the cycle life of the PB film, but it reduces the bleaching speed of the film. 


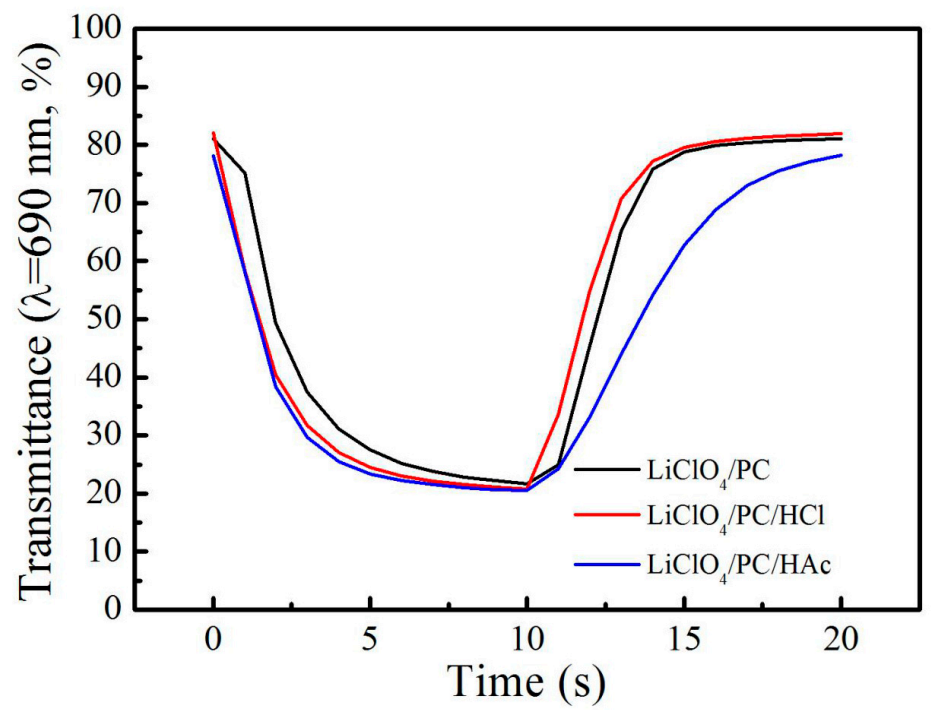

Figure 6. The transmittance response at $690 \mathrm{~nm}$ with switching potential between $-0.05 \mathrm{~V}$ and $0.5 \mathrm{~V}$ for $10 \mathrm{~s}$.

Figure 7a shows the SEM image of the as-electrodeposited PB film. Some particle-like clusters were observed, which can be attributed to the formation of agglomerates during the film deposition. Besides, the film had some cracks between particle-like clusters. Figure $7 \mathrm{~b}$ shows the SEM image of the film after 100 cycles in $\mathrm{LiClO}_{4} / \mathrm{PC}$ electrolyte. The cracks of the film became wider and longer. The SEM result of the PB film after 100 cycles in $\mathrm{LiClO}_{4} / \mathrm{PC} / \mathrm{HCl}$ is shown in Figure $7 \mathrm{c}$, which is similar to the feature of Figure $7 \mathrm{~b}$. Figure $7 \mathrm{~d}$ shows the surface morphology of the PB film after 20,000 cycles in $\mathrm{LiClO}_{4} / \mathrm{PC} / \mathrm{HAc}$. There is no significant difference in the surface morphology of the film after testing compared with that of the as-deposited PB film. The results indicate that the structure of the film was stable during the $\mathrm{Li}^{+}$insertion and extraction processes. The suitable acidic environment can inhibit the destruction of the PB film upon cycling.

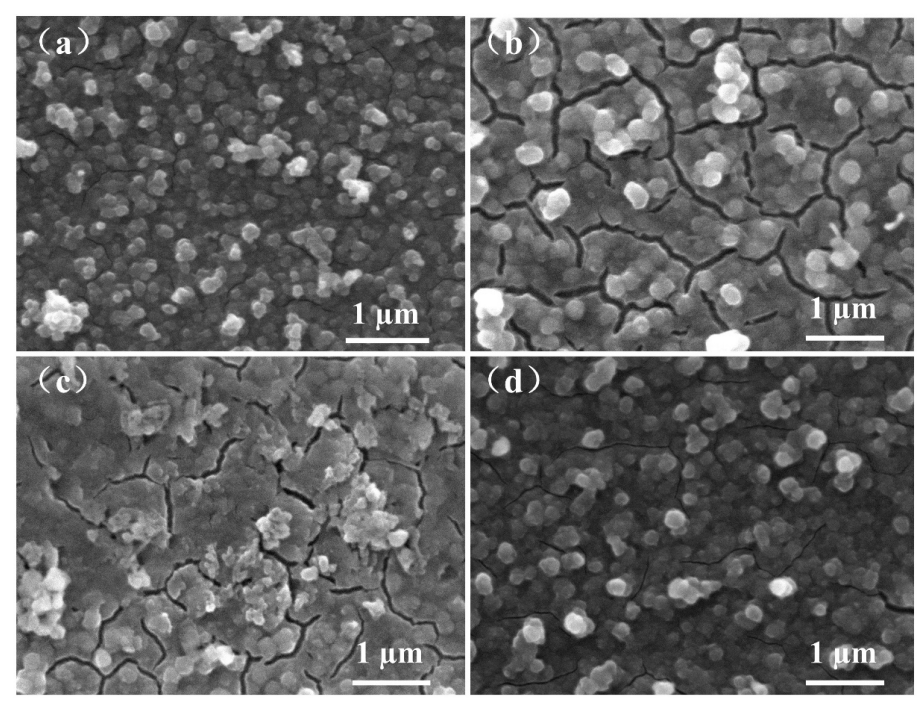

Figure 7. (a) The SEM image of the as electrodeposited Prussian blue (PB) film. SEM images of the PB film after (b) 100 cycles in $\mathrm{LiClO}_{4} / \mathrm{PC}$, (c) 100 cycles in $\mathrm{LiClO}_{4} / \mathrm{PC} / \mathrm{HCl}$, and (d) 20,000 cycles in $\mathrm{LiClO}_{4} / \mathrm{PC} / \mathrm{HAc}$.

The reversibility of the film is expressed as the ratio of the extracted charges $\left(Q_{e x}\right)$ to inserted charges $\left(Q_{\text {in }}\right)$ during the bleaching and coloration processes as follows [32]: 


$$
\text { Reversibility }=\frac{Q_{e x}}{Q_{\text {in }}} \times 100 \%
$$

Figure 8a shows the evolution of the reversibility of the PB film in the three electrolytes. The films cycling in the three electrolytes all exhibited impressive reversibility (more than 91\%), and a slight increase of the reversibility was observed in the cycling. The results imply that most of the inserted charges can be extracted in the following oxidation step. Figure $8 \mathrm{~b}$ shows the evolution of inserted charge capacities of the PB films in the three electrolytes. The inserted charge capacity of the PB film tested in $\mathrm{LiClO}_{4} / \mathrm{PC}$ electrolyte was about $1.9 \mathrm{mC} / \mathrm{cm}^{2}$ at 100 th cycle, which is only $23.6 \%$ of the initial cycle. This implies that the charge capacity of the film was greatly reduced after 100 cycles, which led to the decrease of the electrochromic activity of the film. The PB film, $\mathrm{KFe}\left[\mathrm{Fe}(\mathrm{CN})_{6}\right]$, generally contains an indeterminate amount of water in the interstices of the cubic lattice structure [33]. Meanwhile, the $\mathrm{LiClO}_{4} / \mathrm{PC}$ electrolyte contains a small amount of water molecules. This suggests that the strong interaction between ferric ions and hydroxide ions forms $\mathrm{Fe}(\mathrm{OH})_{3}$, resulting in the destruction of the Fe-CN-Fe bond and in the solubilization of the PB film [34]. The reaction can be written as follows [35]:

From the above results we can see that a cycle lifetime in excess of 20,000 was achieved in $\mathrm{LiClO}_{4} / \mathrm{PC}$ electrolyte containing acetic acid and was much higher than the results of some previously reported works. This suggests that a suitable acidic environment can inhibit the reaction between $\mathrm{Fe}^{3+}$ and $\mathrm{OH}^{-}$to form $\mathrm{Fe}(\mathrm{OH})_{3}$, and that the structure of the film is stable during the $\mathrm{Li}^{+}$insertion and extraction processes. However, the inserted charge capacity of the $\mathrm{PB}$ film tested in $\mathrm{LiClO}_{4} / \mathrm{PC} / \mathrm{HCl}$ obviously decreased as the cycle number increased, indicating that the hydrochloric acid cannot prevent the decomposition of $\mathrm{PB}$ film in $\mathrm{LiClO}_{4} / \mathrm{PC}$ electrolyte. This suggests that $\mathrm{H}^{+}$ions can inhibit the reaction between $\mathrm{Fe}^{3+}$ and $\mathrm{OH}^{-}$to form $\mathrm{Fe}(\mathrm{OH})_{3}$, but excess $\mathrm{H}^{+}$ions in hydrochloric acid will participate in the redox reaction of the $\mathrm{PB}$ film together with $\mathrm{Li}^{+}$ions, which can destroy the lattice structure of the film [36]. The reaction can be written as follows:

$$
\mathrm{XFe}\left[\mathrm{Fe}(\mathrm{CN})_{6}\right]+\mathrm{X}^{+}+e^{-} \leftrightarrow \mathrm{X}_{2} \mathrm{Fe}\left[\mathrm{Fe}(\mathrm{CN})_{6}\right]
$$

where $X$ represents $\mathrm{Li}^{+}$and $\mathrm{H}^{+}$ions.
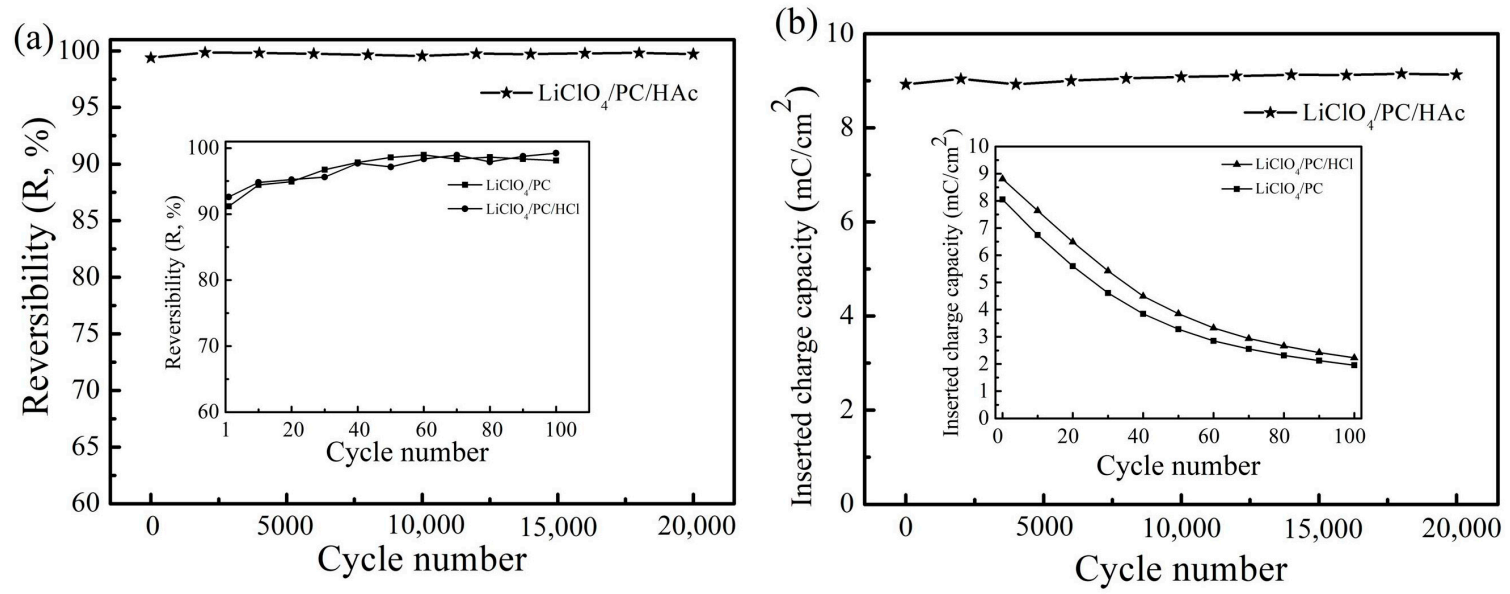

Figure 8. (a) Evolution of the reversibility; (b) the inserted charge capacity of the PB film in different electrolytes.

\section{Conclusions}

In summary, the electrochromic performances of the PB films in $\mathrm{K}^{+}$-based electrolytes with different solution $\mathrm{pH}$ values were investigated. Acidified $\mathrm{KCl}$ solutions can significantly improve the durability of the $\mathrm{PB}$ film, and the $\mathrm{KCl}$ solutions $(\mathrm{pH}=2.15$ and $\mathrm{pH}=3.03$ ) showed better performance. Furthermore, we investigated the cycle stabilities of $\mathrm{PB}$ films in $\mathrm{LiClO}_{4} / \mathrm{PC}$ electrolyte containing 
different acids. The cyclic stability of the PB film did not significantly improve when the hydrochloric acid was dissolved in $\mathrm{LiClO}_{4} / \mathrm{PC}$ electrolyte. Hydrochloric acid partly prevents the film from decomposing during the cycling. However, it may be involved in the redox reaction of $\mathrm{PB}$ and could destroy the lattice structure of the film. The film cycling in $\mathrm{LiClO}_{4} / \mathrm{PC}$ with acetic acid electrolyte exhibited no obvious transmittance fade after 20,000 cycles and had a much greater cycle life than some previously demonstrated PB films. This suggested that the method of adding acetic acid to the electrolyte provided an effective way to improve the cyclic stability of the $\mathrm{PB}$ film in $\mathrm{LiClO}_{4} / \mathrm{PC}$.

Author Contributions: Z.L. designed and performed the experiments; Z.L. and K.Z. analyzed the data; Y.T., K.Z., H.W., and H.Y. supervised and provided advice during the completion of this study.

Funding: This work was supported by the National Key R\&D Program of China (2016YFB0601700) and the Beijing Natural Science Foundation (2161001).

Acknowledgments: This work was supported by the National Key R\&D Program of China (2016YFB0601700) and the Beijing Natural Science Foundation (2161001).

Conflicts of Interest: The authors declare no conflict of interest.

\section{References}

1. Jensen, J.; Krebs, F.C. Form the bottom up-flexible solid state electrochromic devices. Adv. Mater. 2014, 26, 7231-7234. [CrossRef] [PubMed]

2. Liao, C.C.; Chen, F.R.; Kai, J.J. $\mathrm{WO}_{3-x}$ nanowires based electrochromic devices. Sol. Energy Mater. Sol. Cells 2006, 90, 1147-1155. [CrossRef]

3. Wang, J.; Khoo, E.; Lee, P.S.; Ma, J. Synthesis, Assembly, and Electrochromic Properties of Uniform Crystalline $\mathrm{WO}_{3}$ Nanorods. J. Phys. Chem. C 2008, 112, 14306-14312. [CrossRef]

4. Wang, J.M.; Sun, X.W.; Jiao, Z. Application of nanostructures in electrochromic materials and devices: Recent progress. Materials 2010, 3, 5029-5053. [CrossRef] [PubMed]

5. Xia, X.H.; Tu, J.P.; Zhang, J.; Wang, X.L.; Zhang, W.K.; Huang, H. Morphology effect on the electrochromic and electrochemical performances of $\mathrm{NiO}$ thin film. Electrochim. Acta 2008, 53, 5721-5724. [CrossRef]

6. Oliveira, S.C.; Torresi, R.M. Uma visão das tendências e perspectivas em eletrocromismo: A busca de novos materiais e desenhos mais simples. Quim. Nova 2000, 23, 79-87. [CrossRef]

7. Delongchamp, D.M.; Hammond, P.T. Multiple-color electrochromism from layer-by-layer-assembled Polyaniline/Prussian blue nanocomposite thin films. Chem. Mater. 2004, 16, 4799-4805. [CrossRef]

8. Niklasson, G.A.; Granqvist, C.G. Electrochromics for smart windows: thin films of tungsten oxide and nickel oxide, and devices based on these. J. Mater. Chem. 2007, 17, 127-156. [CrossRef]

9. Bonhote, P.; Gogniat, E.; Campus, F.; Walder, L.; Gratzel, M. Nanocrystalline electrochromic displays. Displays 1999, 20, 137-144. [CrossRef]

10. Wang, J.; Zhang, L.; Yu, L. A bi-functional device for self-powered electrochromic window and self-rechargeable transparent battery applications. Nat. Commun. 2014, 5, 4921. [CrossRef]

11. Ho, K.C. Cycling and at-rest satbilities of a complementary electrochromic device based on tungsten oxide and Prussian blue. Electrochim. Acta 1999, 44, 3227-3235. [CrossRef]

12. Takada, K.; Sakamoto, R.; Yi, S.T.; Katagiri, S.; Kambe, T.; Nishihara, H. Electrochromic bis (terpyridine) metal complex nanosheets. J. Am. Chem. Soc. 2015, 137, 4681-4689. [CrossRef] [PubMed]

13. Pai, S.; Moos, M.; Schreck, M.H.; Lambert, C. Green-to-Red Electrochromic Fe (II) Metallo-Supramolecular Polyelectrolytes Self-Assembled from Fluorescent 2, 6-Bis (2-pyridyl) pyrimidine Bithiophene. Inorg. Chem. 2017, 56, 1418-1432. [CrossRef] [PubMed]

14. Wałęsa-Chorab, M.; Banasz, R.; Marcinkowski, D.; Kubicki, M.; Patroniak, V. Electrochromism and electrochemical properties of complexes of transition metal ions with benzimidazole-based ligand. RSC Adv. 2017, 7, 50858-50867. [CrossRef]

15. Burdukov, A.B.; Vershinin, M.A.; Pervukhina, N.V.; Boguslvaskii, E.G.; Eltsov, V.; Shundrin, L.A.; Selector, S.L. Towards the clathrochelate-based electrochromic materials: The case study of the first iron (II) cage complex with an annelated quinoxaline fragment. Inorg. Chem. Commun. 2014, 44, 183-187. [CrossRef] 
16. Wang, Z.; Shi, G.; Xia, J.; Xia, Y.; Zhang, F.; Xia, L.; Song, D.; Liu, J. Facile preparation of a $\mathrm{Pt} /$ Prussian blue/graphene composite and its application as an enhanced catalyst for methanol oxidation. Electrochim. Acta 2014, 121, 245-252. [CrossRef]

17. Soloyev, A.A.; Zakharov, A.N.; Robatkin, S.V.; Kovsharov, N.F. Electrochromic device with polymer electrolyte. J. Electron. Mater. 2016, 45, 3866-3871. [CrossRef]

18. Wang, J.Y.; Wang, M.C.; Jan, D.J. Synthesis of poly(methyl methacrylate)-succinonitrile composite polymer electrolyte and its application for flexible elcetrochromic devices. Sol. Energy Mater. Sol. Cells 2017, 160, 476-483. [CrossRef]

19. Fan, M.S.; Kao, S.Y.; Chang, T.H.; Vittal, R.; Ho, K.C. A high contrast solid-state electrochromic device based on nano-structural Prussian blue and poly(butyl viologen) thin films. Sol. Energy Mater. Sol. Cells 2016, 145, 35-41. [CrossRef]

20. Tung, T.S.; Ho, K.C. Cycling and at-rest stabilities of a complementary electrochromic device containing poly(3,4-ethylenedioxythiophene) and Prussian blue. Sol. Energy Mater. Sol. Cells 2006, 90, 521-537. [CrossRef]

21. Qian, J.; Ma, D.; Xu, Z.; Li, D.; Wang, J. Electrochromic properties of hydrothermally grown Prussian blue film and device. Sol. Energy Mater. Sol. Cells 2018, 177, 9-14. [CrossRef]

22. Wang, Z.; Yang, H.; Gao, B.; Tong, Y.; Zhang, X.; Su, L. Stability improvement of Prussian blue in nonacidic solutions via an electrochemical post-treatment method and the shape evolution of Prussian blue from nanospheres to nanocubes. Analyst 2014, 139, 1127-1133. [CrossRef] [PubMed]

23. Cheng, K.C.; Kai, J.J.; Chen, F.R. Improving the durability of Prussian blue based on nano-composite thin film in $\mathrm{Li}^{+}$based liquid electrolyte. Electrochim. Acta 2007, 52, 6554-6560. [CrossRef]

24. Seelandt, B.; Wark, M. Electrodeposited Prussian blue in mesoporous $\mathrm{TiO}_{2}$ as electrochromic hybrid material. Microporous Mesoporous Mater. 2012, 164, 67-70. [CrossRef]

25. Eftekhari, A. Potassium secondary cell based on Prussian blue cathode. J. Power Sources 2004, 126, 221-228. [CrossRef]

26. Agnihotry, S.A.; Singh, P.; Joshi, A.G.; Singh, D.P.; Sood, K.N.; Shivaprasad, S.M. Electrodeposited Prussian blue film: Annealing effect. Electrochim. Acta 2006, 51, 4291-4301. [CrossRef]

27. Agrisuelas, J.; García-Jareño, J.J.; Moreno-Guerrero, C.; Vicente, R.F. Identification of electroactive sites in Prussian Yellow films. Electrochim. Acta 2013, 113, 825-833. [CrossRef]

28. Stilwell, D.E.; Park, K.H.; Miles, M.H. Electrochemical studies of the factors influencing the cyclic stability of Prussian Blue films. J. Appl. Electrochem. 1992, 22, 325-331. [CrossRef]

29. Shinde, P.S.; Deshmukh, H.P.; Mujawar, S.H.; Inamdar, A.I.; Patil, P.S. Spray deposited titanium oxide thin films as passive counter electrodes. Electrochim. Acta 2007, 52, 3114-3120. [CrossRef]

30. Sagane, F.; Abe, T.; Iriyama, Y. $\mathrm{Li}^{+}$and $\mathrm{Na}^{+}$transfer through interfaces between inorganic solid electrolytes and polymer or liquid electrolytes. J. Power Sources 2005, 146, 749-752. [CrossRef]

31. Wen, R.T.; Granqvist, C.G.; Niklasson, G.A. Eliminating degradation and uncovering ion-trapping dynamics in electrochromic $\mathrm{WO}_{3}$ thin films. Nat. Mater. 2015, 14, 996-1001. [CrossRef] [PubMed]

32. Kondalkar, V.V.; Patil, P.B.; Mane, R.M.; Patil, P.S.; Choudhury, S. Electrochromic performance of nickel oxide thin film: Synthesis via electrodeposition technique. Macromol. Symp. 2016, 361, 47-50. [CrossRef]

33. Buser, H.J.; Schwarzenbach, D.; Petter, W.; Ludi, A. The crystal structure of Prussian blue: $\mathrm{Fe}_{4}\left(\mathrm{CN}_{6}\right)_{3} \cdot \mathrm{xH}_{2} \mathrm{O}$. Inorg. Chem. 1977, 16, 2704-2710. [CrossRef]

34. Salazar, P.; Martín, M.; O’Neill, R.D.; Gonzalez-Mora, J.L. Improvement and characterization of surfactant-modified Prussian blue screen-printed carbon electrodes for selective $\mathrm{H}_{2} \mathrm{O}_{2}$ detection at low applied potentials. J. Electroanal. Chem. 2012, 674, 48-56. [CrossRef]

35. Koncki, R.; Wolfbeis, O.S. Composite film of Prussian Blue and N-substituted polypyrroles: Fabrication and application to optical determination of Ph. Anal. Chem. 1998, 70, 2544-2550. [CrossRef] [PubMed]

36. Liu, C.; Dong, S. Electrochemistry of vanadium hexacyanoferrate film. Electroanalysis 1997, 9, 838-842. [CrossRef]

(C) 2018 by the authors. Licensee MDPI, Basel, Switzerland. This article is an open access article distributed under the terms and conditions of the Creative Commons Attribution (CC BY) license (http:/ / creativecommons.org/licenses/by/4.0/). 